Uluslararası Yönetim İktisat ve İşletme Dergisi, ICAFR 16 Özel Sayısı Int. Journal of Management Economics and Business, ICAFR 16 Special Issue

\title{
MUHASEBE MESLEK MENSUPLARININ ETIKK ALGISI -YALOVA ÖRNEĞİ-
}

\author{
Doc. Dr. Ferhat SAYIM \\ Yalova Üniversitesi İIBF \\ f_sayim@hotmail.com \\ Arș. Gör. Özlem USMAN \\ Yalova Üniversitesi İIBF \\ sozlemozmen@hotmail.com
}

\begin{abstract}
ÖZET
Muhasebe mesleğinin muhasebe temel ilkelerine uygun olarak yürütülmesinde yasal düzenlemelerin yanı sıra meslek etik ilkelerinin de var olması önem arz etmektedir. Çalışmada literatürdeki etik tanımlamaları ele alınmakta, meslek etiği kavramı ayrıca işlenmektedir. Muhasebe meslek mensuplarının etik kavramından ne anladığı ve ortak algının ne olduğu çalışmanın temel sorusudur. Çalışmada Yalova'da faaliyette bulunan muhasebe meslek mensuplarının meslek etiğine bakış açıları ve etik sorunları algılayış biçimlerine yönelik olarak yüz yüze yarı yapılandırılmıs görüşme yöntemi kullanılarak bir inceleme yapılmıştır. Inceleme sonucunda elde edilen cevaplar soru ve konu bazında bir araya getirilerek ortak algı analiz edilmiştir. Bu çerçevede ulaşılan bulgu ve önerilere son bölümde yer verilmiştir.
\end{abstract}

\section{Anahtar Kelimeler: Muhasebe Mesleği, Etik, Meslek Etiği \\ PERCEPTION OF ETHICS OF ACCOUNTING PROFESSIONALS - YALOVA CASE}

\begin{abstract}
The existence of professional ethical principles is important while performing the accounting profession in accordance with the basic accounting principles as well as legal regulation. In this study ethical definitions are discussed in the literature, the concept of professional ethics is examined additionally. The basic question of the study is what the professional accountants understand from the ethical concept and what the common perception is. Working in Yalova professional accountant professional ethics perspectives and perceptions on ethical issues were examined by using semi-structured interviews with face-to-face method. Common perception is analyzed via the answers obtained from the survey were brought together on the basis of questions and issues. In this way, the findings and recommendations which have been mentioned in the last part of the study.
\end{abstract}

Key Words: Accounting Profession, Ethic, Work Ethic 


\author{
Uluslararası Yönetim İktisat ve Isşletme Dergisi, ICAFR 16 Özel Saylsı \\ Int. Journal of Management Economics and Business, ICAFR 16 Special Issue
}

\title{
1. Giriș
}

Her mesleğin yapısından kaynaklanan ve mesleği icra eden mensuplarda bulunması gereken belirli etik değerler söz konusudur. Toplumda ticari faaliyetlerin düzenlenmesinde ve sürdürülebilmesinde muhasebe mesleği kritik öneme sahip olan mesleklerdendir. Muhasebe mesleğinin etkin olarak yürütülmesinde yasal düzenlemelerin yanı sıra meslek etik ilkelerinin de var olması ayrıca önem arz etmektedir. Muhasebe meslek mensuplarının söz konusu muhasebe meslek etiği ilkelerinin bilincinde olmaları ve meslek etiği kavramını algılayış biçimleri, mesleğin gelişmesine ve hem yasalara hem de etik ilkelere uygun olarak sürdürülmesine etki edecektir. Toplumdaki etik algısı ahlak anlayışıyla eşdeğer olarak görülmektedir. Bu algının bileşenleri için bir çok kavram ifade edilebilse de "Eşitlik, Tarafsızlık, Adalet, Dürüstlük, Doğruluk, İyilik Esası, Kötülükten kaçınma, Sadık olmak, Sözünde durmak, Sorumluluk anlayışıyla hareket etmek vb." kavramlar alt bileşenler olarak sayılabilmektedir.

Etik kavramının mesleklerin icrasında ön plana çıkması yerleşik kuralların ve kanunların hayatta karşılaşılabilecek her türlü durumu ve anlaşmazlı̆̆ 1 kavrama ve kapsamada yetersiz kalmasından kaynaklanmaktadır. Bir diğer tabirle kanunların düzenleyemediği ya da kapsayamadığı bir çok durum ve anlaşmazlık için etik-ahlaki ilkeler yol gösterici ve çözümleyici olmaktadır. Siyah ya da beyaz olarak tanımlanamayan gri ya da flu alanların çözümlenmesinde etik yaklaşımlar devreye girmektedir.

\section{Etik Kavramı}

Literatürde etik kavramının çok çeşitli tanımlarına rastlamak mümkündür.

Sözlük tanımına göre etik; “Tavır ve ahlaki davranışların standardıdır.” Toplumda ve yaşamın her alanında kanunların yetersiz kaldığı durumlarda uyulması gereken kurallara ve doğru davranış biçimlerine "etik" denir (Aytulun, 2005:1).

Etik insanların karar ve davranışlarının ne şekilde olup ne şekilde olmaması gerektiğine ilişkin bir değerler bütünüdür. Bireyler, gruplar ve örgütler arasında "doğru" ilişkiler kurulması anlayışını kapsayan bir kavramdır (Özalp, 2004:118).

Etik doğru ve yanlış, iyi veya kötü, haklı veya haksızın ne olduğuna karar vermek demektir (Özdemir, 2003:153).

Etik, ahlaki açıdan doğru-yanlış ya da iyi-kötü ile ilgilidir (Hatcher, 2004: 358).

Etik, felsefenin bir dalıdır; ahlak felsefesidir (moral philosophy) ya da ahlak (morality), ahlaki sorunlar ve ahlaki yargılar hakkında felsefesi düşünmedir (Frankena, 2007:20).

Etik (Ethique) kavramının kökenine bakıldığında, kökenin Yunanca "Ethikos" dan, ethikos kelimesinin de ethos kökünden geldiği anlaş1lır. Ethos; adetler, ananeler, moral ile ilgilidir. Etik, insanlar arasındaki ilişkilerin temelinde yer alan değerlerin, ahlaki bakımdan iyi ya da kötü, doğru ya da yanlış olanın niteliğini ve temelini araştıran felsefe alanıdır (Kotar, 1997:65). 


\section{Uluslararası Yönetim İktisat ve İsletme Dergisi, ICAFR 16 Özel Sayısı Int. Journal of Management Economics and Business, ICAFR 16 Special Issue}

\section{Meslek Etiği}

Meslek etiği "Belirli bir meslek grubunun, mesleğe ilişkin olarak oluşturup, koruduğu; meslek üyelerine emreden, onları belli bir şekilde davranmaya zorlayan kişisel eğilimlerini sınırlayan; yetersiz ve ilkesiz üyeleri meslekten dişlayan, meslek içi rekabeti düzenleyen ve hizmet ideallerini korumayı amaçlayan mesleki ilkeler bütünüdür" (Mocan, 2002). Bir başka tanıma göre ise; meslek etiği, mesleği icra ederken çalışma ortamı içinde neyin doğru neyin yanlış olduğunu öğrenip, doğru olanı seçmektir. Kişisel etik davranış ilkeleri güvenilirliği ve dürüstlüğü, adaleti, başkalarına saygı duyup zarar vermekten kaçınmayı, öz değerleri içerisinde barındırırken; muhasebeciler, yöneticiler, mühendisler ve doktorlar gibi profesyoneller için etik davranış ilkeleri nesnellik, tam açıklama, gizlilik, durum tespiti gibi kavramları ve çıkar çatışmalarını önlemeyi kapsayacak şekilde genişletilebilir (Hansen ve Mowen, 2006: 15).

Mesleki etik, mesleğin yapılmasında karşılaşılan ve o mesleğin içinden ya da dışından kimi insanların etik dışı davranış sorunlarının giderilmesi ya da azaltılması gereğinden doğmuştur ve insanların belirli bir mesleği icra etmesi sırasında ne yapıp ne yapmaması gerektiği sorusuna ilişkin yanıtlar aramaktadır (Tepe, 1997:73).

Meslek etiğini daha genel bir ifadeyle "Her türlü meslek alanında meslek mensuplarının davranış ve tutumlarının toplumların yapısına bakmaksızın evrensel boyuta kavuşturmak için oluşturulmuş kurallar ya da ilkeler” (Ayboğa, 2001:31) şeklinde tanımlamak mümkündür.

Aynı meslekte çalışan bireylerin,belirlenen davranış kurallarına uygun davranma gerekliliğii, meslek etiğinin önemini oluşturur. Mesleki etiğin temelinde insan ilişkileri yatar ve aynı meslekten bireylerin birbirleriyle olan ilişkilerinde belirli davranış kalıplarına uymaları meslek etiğinin gereğindendir (Aydın, 2002:75).

Meslek etiklerinde sorulan sorular ise belirli bir mesleği icra ederken kişinin ne yapması ya da ne yapmaması gerektiğine ilişkin sorulardır. Söz konusu soruların cevapları uluslararası bildirgeler, sözleşmeler ve meslek etik kodları olarak ortaya çıkmaktadır (Kuçuradi, 2009:28).

Son yıllarda, mesleki ve etik değerlere sahip olmayan bir meslek düşünülemez. Mesleki ve etik değerler, mesleklere kişilik kazandıran, mesleği belirli normlara oturtan değerlerdir ki bunlar iş dünyasında sağlıklı, başarılı ilişkilerin geliştirildiği ortamları meydana getirmektedir. $\mathrm{Bu}$ bağlamda da etik değerler toplumun refah düzeyini arttırmakta, daha kültürlü ve bilinçli bir toplum oluşturulmasına yardımcı olmaktadır (TESMER, 2010:217).

\section{Temel Etik Yaklaşımlar}

Temel etik yaklaşımları Teleolojik Yaklaşım, Deontolojik Yaklaşım, Diolojik İdealizm Yaklaşımı ve Relativist Yaklaşım olarak sıralamak mümkündür. Teleolojik ve Deontolojik Yaklaşımların alt başlıkları da bulunmaktadır. Yaklaşımlar özet tanımlamalar ile aşağıdaki şekilde sistematize edilebilir (Sayım, 2011: 49):

\section{4..1 Teleolojik Yaklaşım}

Teleoloji, bir davranış ve kararın eylem veya sonuçlarının ahlak kurallarına 
Uluslararası Yönetim İktisat ve Işsetme Dergisi, ICAFR 16 Özel Saylsı

Int. Journal of Management Economics and Business, ICAFR 16 Special Issue

uygunluk derecesini değerlendirmeyi ifade eder. Başka bir ifade ile teleoloji, bir davranışın sonucunun iyi olmasından ötürü doğru olmasıdır. Amaç, sonucu en iyi olan çıktıları seçmektir.

\subsubsection{Bireysel Yaklaşım}

Egoizm teorileri olarak ta geçebilmektedir. Hazcıllk ve Ahlaki Egoizm olarak da ayrışabilmektedir (Özgener, 2004: 3-34). "Uzun dönemde bireye yarar sağlayan davranış doğrudur” şeklinde kısa bir tanımlama yapılabilmektedir.

\subsubsection{Faydacı Yaklaşım}

Bir davranış ya da kararın ilişkili tüm insanlar için meydana getirebileceği “iyi”nin toplam değeri üzerinde durur.

\subsection{Deontolojik Yaklaşım}

Mesleğin genel tanımından gelen ya da zamanla elde edilen bilgi birikiminin sonucuna göre belirlenmiş "iyi” ve "kötü’lerin ya da "yapılması gereken" ve "yapılmaması "gereken’lerin ön plana çıkartılmasıdır. Faydaya dayalı ölçümler mesleğin kuralları karşısında geri plandadır.

\subsubsection{Ahlâk ve Haklar Yaklaşımı}

İnsanların irade, mahremiyet, gelişme, güvenlik, yaşama gibi hakları ve özgürlükleri bulunduğunu, karar alma süreçlerinde bu hak ve özgürlüklerin göz ardı edilememesi üzerine dayandığı söylenebilir.

\subsubsection{Adaletçi Yaklaşımı}

Eşitlik, adalet ve tarafsızlık ilkeleri üzerinde durur. Farklılıkların, kuralların ve sorumlulukların açıkça ve hakkaniyetli bir şekilde ortaya konmasını gerektirir.

\subsection{Diolojik İdealizm Yaklaşım}

Somut olarak geçerli evrensel kuralların ortaya konamayacağından hareketle uygulamalı etik ilkeler belirleme yerine iletişimi ön plana çıkarır. Açık bir iletişim ile sağlanacak kuralları tarafların kabulü esas olmaktadır. Özellikle çıkar çatışması yoğunluğunun yüksek olduğu alanlar için geçerliliği yüksek olacaktır.

\subsection{Relativist Yaklaşım}

"Saf, Rol, Sosyal Grup, Kültürel" Relativizm gibi ayrı ayrı da tanımlanabilmektedir (Özgener, 2004:48-50). Mutlak etik kural reddedilmektedir. Dahil olunan grup üyelerinin fikir ve davranışlarının gözlemlenmesi suretiyle davranış ya da fikir birliği sağlanmışsa bu davranış ya da fikrin etik ve doğru olduğunu kabul eder. Bu yaklaşımda bir durum için doğru kabul edilenin başka bir durum için yanlışlğ̆ı söz konusudur.

\section{Muhasebe Mesleğinde Etik}

Mesleki başarının önemli anahtarlarından biri de şüphesiz mesleki ve etik 


\section{Uluslararası Yönetim İktisat ve İsletme Dergisi, ICAFR 16 Özel Sayısı Int. Journal of Management Economics and Business, ICAFR 16 Special Issue}

değerlerdir. Bu kavramlar muhasebe mesleği açısından gelişmiş ülkelerde 1960'l1 yıllarda gündeme gelmişken ülkemizde ancak 1995'li y1llardan sonra gündeme gelmeye başlamış ve 2000'li yıllarda da giderek önem kazanmıştır. Günümüzde ise gerek iş dünyasında gerekse muhasebe dünyasında artık olmazsa olmazlar arasında yerini almıştır.

Muhasebe mesleğinde etik, kanunlara uygun işlemlerin yanında toplumun güncel değer yargılarına da önem vererek güvenilir bilgilerin topluma sunulmasıdır (Sözbilir, 2000:46). Bu anlamda muhasebe mesleği için düzenlenen mesleki etik kurallarının üç özelliği bulunmaktadır. Bu özellikler meslek mensubunun topluma olan sorumluluklarını vurgulamaktadır ki bu kurallara göre meslek mensubu (TESMER, 2010:235);

1. Bağımsız, dürüst ve tarafsız olmalıdır,

2. Mesleğin gerektirdiği teknik bilgi; deneyim ve yeterliliğe sahip bulunmalıdır,

3. Mükelleflerine hizmet sunarken mesleki özen ve titizliği göstermeli ve sorumluluklarının bilincinde olmalıdır.

Muhasebe meslek mensuplarının, meslekleri ile ilgili hem yasal hem de etik kurallara uymaları oldukça önemlidir. Yasal kurallara uygun davranmak, muhasebe mesleği ile ilgili yasalara uymayı kapsarken; etik kurallara uygun davranmak, meslekte kabul gören değer yargılarına göre davranmayı ifade eder. Etik davranış, karar veya eylemin yasal olup olmadığından çok, doğru ya da yanlış olup olmadığının veya mesleki değerlere uygun olup olmadığının değerlendirilmesini gerektirir Muhasebede etik yaklaşım, adalet, tarafsızlık, gerçeklik ve doğruluk kavramlarına dayandırılabilir (Gül ve Ergün, 2004:57-58).

Muhasebe etiği; muhasebeciler tarafindan oluşturularak, aynı zamanda muhasebe ile ilgili olan taraflarca da kabul edilen mesleki ilkeler bütünüdür. Bu doğrultuda muhasebe uygulamalarında göz önünde tutulması gereken bazı ilkeler şu şekilde sıralanabilir (Aydın ve Akdoğan, 1987:209):

- Muhasebe ilgili tüm tarafları eşit tutmalıdır,

- Hazırlanan finansal raporlar yanlış yorumlamaya meydan vermeyecek doğru ve hatasız ifadeler sunmalıdır, olmalidir

- Muhasebe verileri özel çıkarlara hizmet etmeksizin, doğru, önyargısız ve tarafsız

Muhasebe mesleğinin etik kuralları olarak da belirlenen ve meslek mensuplarının genel davranış biçimlerini tanımlayan yukarıdaki ilkelerin 3 temel işlevi olduğu ifade edilmektedir. Bunlar (Aydın, 2002:76);

- Yetersiz ve ilkesiz üyeleri ayırmak,

- Meslek içi rekabeti düzenlemek,

- Meslek ideallerini korumak.

Michael Josephson "Muhasebe Uygulamalarında Etik Konular" kitabının 1. bölümünde "10 Evrensel Değer” kaydeder. Bunlar; "Dürüstlük, Güvenirlik, Yemine sadakat, Vefa, Adalet, Şefkat, Başkalarına saygl, Sorumlu vatandaşlık, Mükemmellik saylsl ve Mesuliyet"tir (Smith \& Smith, 2007:382).

Muhasebe alanında AICPA (American Institute of Certified Public Acoountants) ise toplumun muhasebe ihtiyaçlarını karşılayanlar için bir kurallar bütünü oluşturmak ve bu konuda zorlayııı olmak görevini üstlenmiştir. İşletme Muhasebecileri Enstitüsü ve 


\section{Uluslararası Yönetim İktisat ve İsletme Dergisi, ICAFR 16 Özel Sayısı \\ Int. Journal of Management Economics and Business, ICAFR 16 Special Issue}

Dahili Denetçiler Enstitüsü de etik kuralları oluşturmaktadır. Profesyonel muhasebe organizasyonları muhasebe uzmanlarının üyelerine etik rehberleri sağlama sorumluluğunu yükler (Smith \& Smith, 2007:383).

Ülkemizde ise muhasebe meslek etiği ile yapılan düzenlemelerde; mesleki yeterlilik, bağımsızlık ilkeleri, mesleki özen ve titizlik, ticaret ve mesleğe aykırı faaliyet yasağı, reklâm yasağı, sır saklama yükümlülüğü, karşılıklı ilişkiler ve haksız rekabet ve ekip çalışmasında görev, yetki ve sorumluluk dağılımı gibi başlıklar dikkat çekmektedir.

\section{Muhasebe Meslek Etiği Algısı Üzerine Yalova İli Uygulaması*}

$\mathrm{Bu}$ bölümde Yalova ilinde faaliyette bulunan muhasebe meslek mensupları üzerinde yapılan araştırmadan ve araştırmanın bulgularından bahsedilmektedir.

\subsection{Araştırmanın Amacı}

Araştırmanın amacı, Yalova ilinde faaliyette bulunan muhasebe meslek mensuplarının meslek etiğine bakış açıları ve etik sorunları algılayış biçimlerine yönelik bir inceleme yapmaktır. Son yıllarda literatürde giderek artan bir oranda ele alınan muhasebe meslek etiği konusuna katkı sağlayabilmek araştırmanın diğer bir amacı olarak ifade edilebilir.

\subsection{Literatürde Yapılan Çalışmalar}

Konuyla ilgili olarak daha önce yapılan çalışmalar incelenmiş ve bunların bir kısmı amaç ve sonuçları itibariyle aşağıda sıralanmıştır.

Albez ve Yıldırım, (2005) Erzurum'da muhasebecilerin meslek etiği ile ilgili tutumlarını araştırmış ve çalışmasının sonucunda muhasebe meslek mensuplarını meslek etiğinden sapmaya zorlayan en önemli baskı grubunu mükelleflerin oluşturduğunu belirtmiş̧tir. Bunun nedenini ise meslek mensuplarının mükelleflere karşı olan parasal bağımlılıkları ve mükelleflerin isteklerini yapabilecek başka meslek mensubu bulabilme firsatlarına bağlamıştır.

Aymankuy ve Sarığlan (2005)'ın Balıkesir il merkezinde yaptığı çalışmada ise Balıkesir il merkezindeki muhasebe meslek mensuplarının genel olarak eğitim seviyelerinin yüksek olmasına rağmen, etik kavramının, felsefi açıdan, mesleki yaşamda uygulanması ve uygulanabilirliği konusunda fikir farklılıkları yaşadıkları sonucuna ulaşılmıştır.

İşü̈den ve Çabuk, (2006) meslek etiği ve meslek etiğinin meslek yaşamı üzerindeki etkilerini Balıkesir ilinde faaliyet gösteren meslek mensupları üzerinde uyguladığı anket çalışması ile incelemiştir. Çalışmada, meslek mensuplarının meslek etik ilkelerine önem vererek farkındalık düzeylerinin yüksek olduğu, etik sapmaların genelde mükelleflerin, meslek mensuplarının ve piyasadaki rekabet ortamının etkisiyle oluştuğu, meslek mensuplarının mükellefin ya da kendisinin çıkarlarının gerçekleştirmeye çalışırken başkalarının ya da devletin çıkarlarını göz ardı etme durumunda kaldıkları, meslek mensuplarının etik ilkelere gerekli özeni göstermedikleri takdirde, bundan

\footnotetext{
* Daha önce yayınlanan bir kitapta araştırma sonuçlarına yer verilmiştir. Bu bildiri ile araştırmanın özetlenmiş sonuçlarının daha geniş kitlelere ulaştırılması hedeflenmektedir.
} 


\section{Uluslararası Yönetim İktisat ve İsletme Dergisi, ICAFR 16 Özel Sayısı Int. Journal of Management Economics and Business, ICAFR 16 Special Issue}

olumsuz etkileneceklerini düşünerek etik ilkelere ve etik ilkelere aykırı olan davranışlara karşı duyarlı oldukları, fakat bu konuda yeterince titiz davranmadıkları sonuçlarına ulaşılmıştır.

Kirik (2007), çalışma konusuyla ilgili olarak Afyonkarahisar'da muhasebe meslek mensupları ile yaptığ 1 ankette; hata ve hilelerin yoğunlukta olduğu bu durumunda muhasebe meslek etiğinde sapmalara neden olduğu sonucuna ulaşmıştır. $\mathrm{Bu}$ durumun temelinde mükellefler, hükümet politikaları, vergi uygulamaları, toplumsal yapı gibi faktörlerin de etkili olduğuna değinmiştir.

Bilen (2008), Doğu Anadolu Bölgesinde muhasebe meslek mensupları üzerinde yaptığı çalışmasında meslek mensuplarının tahsilat, meslektaşlar arasındaki rekabet, ücret tarifesinin altında defter tutulması ve ücret yetersizliği olarak en önemli dört sorunu olduğu sonucuna ulaşmıştır.

Sakarya ve Kara (2010), Balıkesir, Bursa, İstanbul ve İzmir’de yapılan çalışmada muhasebe meslek mensuplarının etik algılamalarının cinsiyete göre genel olarak farklılaşabildiği, eğitim düzeyine göre yapılan karşılaştırmada meslek mensuplarının dürüstlük, tarafsızlık, mesleki yeterlilik ve özen, gizlilik, mesleki davranış ve genel olarak etik algılaması için farklılaşma görülmediği, unvana göre yapılan karşılaştırma sonucunda meslek mensuplarının ünvanları ile dürüstlük ve mesleki davranış değişkeni arasında anlamlı farklılıkların bulunduğu, mesleki deneyime göre yapılan karşılaştırma sonucunda meslek mensuplarının mesleki yeterlilik ve özen ile mesleki davranış değişkenlerine ilişkin bakış açılarında anlamlı farklılıkların olduğu, mükellef sayısına göre yapılan karşılaştırma sonucunda meslek mensuplarının tarafsızlık değişkenine ilişkin meslek etiğine bakış açılarında anlamlı farklılığın olduğu, gelir düzeyine göre yapılan karşılaştırma sonucunda meslek mensuplarının dürüstlük, tarafsızlık, mesleki yeterlilik ve özen, gizlilik, mesleki davranış ve genel olarak etik algılaması alanlarıyla ilgili, herhangi bir farklılığın bulunmadı̆̆ı, dolayısıyla, her gelir düzeyindeki meslek mensuplarının, etiğe bakış açıları yönünden herhangi bir farklılığın olmadığını belirlemiştir.

Kısakürek ve Alpan (2010) da, Sivas ilinde yaptıkları çalışmada, etik kurallara uyulmasında çevresel baskıların, alınan eğitimlerin, meslek örgütlerinin denetimlerinin, cezai ve vicdani yaptırımların etkili olduğu sonucuna varırken etik dışı davranış nedenlerini ise meslek mensubunun daha fazla para kazanma tutkusu, kişisel ahlaki zayıflık ve eğitim kurumlarında meslek etiği derslerinin zorunlu olmaması şeklinde analiz etmişlerdir.

\subsection{Araştırmanın Evreni ve Örneklemi}

Araştırmanın evrenini Yalova ilinde faaliyet bulunan toplam 230 adet meslek mensubu oluşturmaktadır. Araştırmanın örneklemini ise tesadüfi örneklem (random sampling) yoluyla seçilen 30 adet meslek mensubu oluşturmaktadır.

\subsection{Araștırmanın Kısıtlılıkları}

Son yıllarda giderek artan bir oranla araştırılan kurumlarda ve mesleklerde etik konulu araştırmalar içerdiği az bilinen kavramlar, meslekler için yeni uygulamalar, düzenlenmemiş gri alanlar, pazar genişlemesi, meslekteki kişi sayısının hızla artışı gibi 
Uluslararası Yönetim İktisat ve İşletme Dergisi, ICAFR 16 Özel Saylsı Int. Journal of Management Economics and Business, ICAFR 16 Special Issue

nedenlerle zorluklar içerebilmektedir. Muhasebe mesleğindeki etik ve etik dişı uygulamaların, meslekte etik konusuna bakışın araştııılmasını hedefleyen bir araştırmada şu zorluklardan bahsedilebilir.

- Etik kavramının literatürde ahlak kavramıyla eşleştirilmesine rağmen meslek mensupları ve diğer ilgililer arasında farklı tanımlamalara konu olması,

- Kelimenin toplum içerisinde yaygınlığının henüz istenen noktalara gelmemesi,

- Genel bir kanaat olmasına karşın tam kapsamının genel olarak bilinmemesi,

- Geleneksel ahlak anlayışı ve kavramından farklı olduğu izlenimine rağmen hangi temeller üzerine konumlandırılacağının bilinmemesi,

- Mesleklerde etik sorun alanlarının genişlemeye ve değiş̧ime açık olması,

- Meslek mensuplarının yoğun iş ortamı, verilerin yanlış kullanımı vb. sebeplerle klasik anket doldurma faaliyetlerine yanaşmayacak olması, vb. sebeplerle şıklara dayalı bir anket formunun oluşturulmasında zorluk çekilmiş ve araştırma için yedi soruyu içeren görüşmeye dayalı bir anket formu hazırlanmıştır. Araştırma 2011-2012 yıllarında yapılmış olup, daha önce yayınlanan bir kitapta araştırma sonuçlarına da yer verilmiştir. $\mathrm{Bu}$ bildiri ile araştırmanın özetlenmiş sonuçlarının daha geniş kitlelere ulaştırılması hedeflenmektedir.

\subsection{Veri Toplamada Kullanılan Yöntem}

Yalova ilinde faaliyette bulunan muhasebe meslek mensuplarının muhasebe mesleğinde etik konusundaki yaklaşımları, derinlemesine bilgi elde etmek amacıyla nitel araştırma yöntemlerinden biri olan yarı yapılandırılmış görüşme yöntemi kullanılarak araştırılmıştır. Görüşme formlarının hepsi aynı araştırmacı tarafından muhasebe meslek mensubuyla ortalama yarım saat süren yüz yüze görüşme yöntemiyle doldurulmuş ve değerlendirmeye alınmıştır. Görüşme anında, görüşme yapılan araştırmacılar için önceden hazırlanmış soruların yanı sıra görüşme esnasında sorular içinde yer alan bazı konuların daha derinlemesine irdelenmesi amacıyla yeni sorular türetilmiş ve sorulmuştur.

\subsection{Görüşme Formunun Oluşturulması}

Araştırmaya geçilmeden önce muhasebe mesleğinde etik konusuyla ilgili çalışmalar detaylı incelenerek, meslek mensuplarıyla konunun algılanışına dair fikir alışverişinde bulunulmuştur. Konu ile ilgili karşılaşılabilecek sorunlar ve odaklanılması gereken noktalar tespit edilmeye çalışılmıştır. Bu çerçevede yüz yüze görüşmelerin yönetilmiş bir hazırlık safhasından sonra gerçekleştirilmesi sağlanmıştır.

Görüşme formunda 7 adet soru kullanılmıştır. Sorular belirlenirken hedeflenen stratejiler parantez içinde belirtilmiştir.

Soru 1- Muhasebede etik sorunlar nedir? Ne anlama gelir? (Kitlenin etik kavramından ne anladığının ortaya çıkarılması ve araştırmacının meslek mensuplarını daha yakından tanıması hedeflenmiştir).

Soru 2- Etik sorunlar hangi muhasebe faaliyetlerinde daha çok yer alır? Bilanço hazırlama? Beyanname hazırlama? Vergi hesaplamaları? vb. (Kitlenin kendisini ifade 


\section{Uluslararası Yönetim İktisat ve İsletme Dergisi, ICAFR 16 Özel Sayısı Int. Journal of Management Economics and Business, ICAFR 16 Special Issue}

etmesine olanak sağlamak üzere mükellef ile yaşayabileceği etik sorunları benzer başlıklar altında ifade etmesine olanak sağlanmaktadır. Ayrıca araştırmacının mesleki faaliyetlere dair uygulamada teorik bilgilerin dışına çıkması amaçlanmıştır).

Soru 3- Beyanname hazırlanmasında etik sorunlara yol açma potansiyeli var mıdır? Hangi beyanname türünde daha çoktur? (Meslek mensuplarına bu konuda ayrıntılı bilgi vermesi için çağrıda bulunulmaktadır. Ayrıca araştırmacının bu konu üzerine eğilmesi ve bu konuya ilişkin ayrıntılı değerlendirmeler yapması hedeflenmiştir).

Soru 4- Odaların disiplin kurullarına gelen sorunların içeriği genel olarak hangi konularda yoğunlaşır? (Hukuki anlaşmazlıklara konu olan ve yazıya dökülen etik konuların tespiti amaçlanmaktadır. Bu sorunun cevaplarının diğer sorulara verilen cevapları kapsayıp kapsamadığı önemli bir veri olacaktır. Konuyla ilgili yasal düzenlemelerin ve meslek örgütü uygulamalarının konuyu ne derece kapsadığı analiz edilebilecektir).

Soru 5- Yeni mükellef aramada ya da mükellefle ilgili konularda etiksel sorunlar yaşanıyor mu? (Diğer önemli bir etik sorun alanının konuşulması istenmektedir. Bu konunun belki de en çok üzerinde durulan konu olacağı, etik sorunlar deyince diğer konulardan ziyade bu konunun ön plana çıkarılacağı öngörülmüştür).

Soru 6- Muhasebe mesleğinde etiği içeren ne tür düzenlemeler yapılabilir? (Meslek mensuplarının etik sorunlar konusunda algıları alındıktan ve farkındalık oluşturulduktan sonra bu soru özellikle sorularak meslek mensuplarının varsa çözüm önerilerinin alınması, ayrıca meslek mensuplarının yerel, ulusal, uluslararası çözüm önerilerine yatkınlığının araştırılması amacıyla bu soru sorulmuştur).

Soru 7- Vergi affı etik sorunları tetikler mi? (Meslek mensuplarının vergi aflarının sonuçlarına ilişkin düşüncelerinin tespit edilmesi, ayrıca bu konuya etik yaklaşımlarının ne olduğunun tespiti amaçlanmıştır).

\subsection{Araştırma Bulguları}

Araştırmanın sonuçları derlenip konu bazında ele alındıktan sonra ortaya çıkan eğilimler aşağıdaki gibi sıralanabilir.

Etik Sorun Tanımlaması: Meslek mensuplarının genellikle ücret konusundaki rekabeti etik sorun olarak tanımladıkları görülmüştür. Bunun yanı sıra bazı muhasebe meslek mensuplarının mükelleflerinin istekleri üzerine kredi alabilme ya da düşük vergi ödeme gibi taleplerinden ötürü bilançoda oynamalar yapılabildiği söz konusu edilmiştir. Meslek mensuplarının sorunları ifade ederken genel olarak duyum şeklinde ifade ederek kendileri dışında bu faaliyetlerin gerçekleştiği yönünde beyanda bulundukları görülmüştür.

Etik Sorun Algısında Bütüncül Yargının Olmayışı: Etik sorunların algılanışına ilişkin genel sorularda meslek mensuplarının ücret tarifesi ve tahsili dışındaki etik konuları genel etik sorun olarak algılamadıkları ya da fazla gündeme getirmedikleri ve ifade etmekten kaçındıkları görülmüştür. Ancak beyanname türlerine ilişkin özellikli sorulara verdikleri cevaplarda etik sorunların özellikle muhtasar beyanname olmak üzere beyanname hazırlama sürecinde ortaya çıktığını ifade etmektedirler. Bu durum meslek mensuplarının vergiye ilişkin sorunları gizleme çabasından meydana gelebileceği gibi, 


\section{Uluslararası Yönetim İktisat ve İsletme Dergisi, ICAFR 16 Özel Sayısı Int. Journal of Management Economics and Business, ICAFR 16 Special Issue}

meslek mensuplarının etik kavramının kapsamına ilişkin bütüncül yargılarının henüz tam oluşmadığı şeklinde de yorumlanabilir.

Etik Sorun ve Haksız Rekabet İlişkisi: Meslek mensuplarının hemen hemen hepsi ücret kırma ya da fiyat tarifesine uymamayı etik bir sorun olarak görmektedirler. Ancak bu durumu haksız rekabet olarak tanımlayan az sayıda meslek mensubuyla karşılaşılmıştır. Bu durum meslek mensuplarının etik sorunları üst başlıklarla ifade etme noktasında sıkıntı yaşadığı şeklinde ifade edilebilir.

Meslek Odası Görevinin Etik Algısı Üzerindeki Etkisi: Yapılan görüşmelerden elde edilen bir başka izlenim ise meslek mensuplarının meslek odası yönetiminde yer alıp almadığına göre, meslek mensubunun ekonomik düzeyine göre, meslek mensubunun defterlerini tuttuğu mükelleflerin türüne ve büyüklüğüne göre etik sorunları ifade etme ve algılamasının değiştiğidir. Örneğin oda yönetiminde görevli meslek mensuplarının etik sorunların varlığı konusunda daha muhafazakar bir tutum sergiledikleri görülürken diğer meslek mensuplarının kendi aralarında daha fazla etik sorunları ve bazı eğitim eksiklikleri gibi sorunları raporlayabildikleri görülmüştür.

Meslek Mensupları Arası İletişim ve İlişkilerin Etkisi: İl dahilinde meslek mensupları arasındaki iletişimin kuvvetli olması ve meslek mensuplarının genelde birbirlerini tanımasından dolayı; meslek mensuplarının diğer meslektaşları aleyhine konuşmasının pek söz konusu olmadığı anlaşılmıștır. Ancak bayan meslek mensupları arasında, bu durumun tersine dönük bir algının var olduğu söylenebilir. Ayrıca bazı meslek mensuplarına göre ise meslek mensubunun kendi faaliyetlerini överek dolaylı yoldan meslektaşının faaliyetlerini kötülemesi de söz konusu olabilmektedir.

Mükellef Temini Çabalarının Etkisi: Özellikle iş hayatına yeni atılan meslek mensuplarının yeni mükellef edinme sürecinde etik ikilemleri daha yoğun bir şekilde yaşadıkları belirlenmiştir. Meslek mensuplarının bir çoğuna göre meslekte yeni olan meslek mensubunun yeni mükellef arama konusunda etik ikilemler yaşaması kaçınılmazdır. Bunun yanında mükellef ile ilgili konularda hemen hemen bütün meslek mensupları etik sorun yaşayabildiklerini söylemişlerdir. Bu durumun nedenleri bir yandan yeni mükellef aramada ve elde etme çabası sürecinde yaşanan sıkıntılar olurken bir yandan da var olan mükellefi elde tutma çabasından kaynaklanır. Yeni mükellef arama ya da mevcut mükellefi elde tutma çabasındaki meslek mensuplarının etik dışı faaliyetleri ise genelde mesleğin dışında danışmanlık vb. işler yapma taahhüdünde de bulunmak suretiyle haksız rekabete yol açma, mükellef kazanmada yalan beyanda bulunma şeklindedir. Ücretin ise bu aşamada diğer meslektaşlardan daha düşük söylendiği belirtilmektedir.

Etiğe Aykırılığın Azaltılmasında Düzenlemeler: Muhasebe mesleğinde etiği içeren düzenlemelerin neler olabileceği sorusuna muhasebe meslek mensuplarının farklı bakış açıları mevcuttur. Bir kısım muhasebe meslek mensubu, etik kuralların ihlalinde verilen cezaların daha caydırıcı hale getirilmesini savunurken, bir kısım muhasebe meslek mensubu ise disiplin kurulları tarafından verilen cezaların arttırılması yerine işlenen etik suçların nedenleri üzerine araştırmalar yapılarak baskı kaynağının nerden kaynaklandığının araştırılması gerektiğini savunmaktadır.

Eğitim Gereksinimi: Yapılan görüşmelerden ortaya çıkan diğer bir sonuç ise 


\section{Uluslararası Yönetim İktisat ve İsletme Dergisi, ICAFR 16 Özel Sayısı Int. Journal of Management Economics and Business, ICAFR 16 Special Issue}

eğitime meslek mensuplarının fazlaca önem verdiğidir. Genelde etik sorunların başlangıcında mükellef baskısının yer aldığından hareketle devletin mükellefini de eğitmesi gerektiği, savunulan görüşler arasındadır. Ayrıca meslek mensuplarının taleplerinin; etik konulu eğitimlerin sürekli hale getirilmesi, seminer, sunum ve konferansların sıklıkla tekrarlanması, meslek mensuplarıyla sürekli iletişim halinde bulunulması doğrultusunda olduğu görülmüştür.

Ücret Sistemi Gerekliliği: Ücret konusunda yaşanan etik sorunların çözümüne yönelik olarak ise meslek odalarının, meslek mensupları arasındaki hem iletişimi hem de etik bilinci arttırıcı faaliyetlerde bulunması gerektiği ve ücretlerin toplanması konusunda, ücretin meslek mensubu tarafından değil, mali müşavirler odası ya da Maliye Bakanlığı'nın veznelerine yatırılması şeklinde bir sistem geliştirilmesi fikri mevcuttur.

Vergi Affı ve Etik İlişkisi: Vergi affının etik sorunları tetikleyip tetiklemeyeceğine muhasebe meslek mensupları açısından bakıldığında, yaygın olarak tetikleyeceği yorumunun hakim olduğu gözlenmiştir. Bunun temel nedenlerini ise; çıkarılan vergi aflarının vergi ödeme isteğini engelleyeceği, mükellefi vergisini geç ödeme ya da ödememe konusunda cesaretlendireceği, düzenli ödeyen mükellefin kendisini cezalandırılmış hissederek adaletsizlik duygusunun doğacağ gibi görüşler oluşturmaktadır. Bunun yanında az da olsa, vergi bilincinin kişinin tamamen vicdani ve ahlaki yapısıyla alakalı bir durum olduğunu ve bu sebeple çıkarılacak olan vergi aflarının etik sorunları tetiklemeyeceği görüşünü savunan meslek mensuplarının da bulunduğu görülmüştür.

\section{Sonuç ve Öneriler}

Etik kavramıyla ilgili uzlaşılmış tek bir ortak tanımın bulunmamasına rağmen gerek sosyal hayatta gerekse iş dünyasında bir takım düzensizliklerin ortaya çıkmasıyla beraber bu kavrama ilişkin araştırmalar ve incelemeler yoğunlaşmıştır. Etik kavramı en genel ifadeyle iyi ve kötüyü, doğruyu ve yanlışı ayırt etmeye yarayan bir disiplindir. Herhangi bir davranışın etiğe uygun olup olmadığı hem birey hem de toplum açısından değerlendirilmektedir. Buna rağmen bir konu üzerinde verilen etik kararlar genellikle öznel bir özelliğe sahiptir. Farklı kişiler aynı koşullarda farklı etik karar süreçlerinden geçerek sonuçta farklı kararlara ulaşabilmektedirler.

Yaşamın hemen her alanında etik sorunlarla karşılaşılabilir durumda olunması ve bireylerin çoğu kez etik ikilemlerle baș etme çabaları etik kurallara dayalı düzenlemelerin de ortaya çıkmasını kaçınılmaz kılmıştır. Etik kurallara dayalı düzenlemelerin özellikle son yıllarda iş yaşamında yoğun olarak ele alınması meslek etiği kavramını ortaya çıkarmıştır. Meslek etiği, belirli bir meslek grubu tarafından faaliyette bulunulan mesleğe yönelik olarak oluşturulan kurallara uygun davranılmasını sağlayan ilkeler bütünüdür. Meslek etik kurallarının oluşturulması önemlidir. Çünkü bu kuralların belirlenerek her meslek mensubunun bu kurallara riayet etmesi, meslek faaliyetlerinin güvenilir bir şekilde yürütülmesi açısından önemlidir. Her meslek türünde geçerli olarak bir mesleki olayın çözümünde mesleki yeterlilik, mesleki bilgi ve beceri, tecrübe, teknoloji kullanabilme gibi özelliklerin yanı sıra dürüstlük, doğruluk, sözünde durmak, sadakat, adaletli davranmak vb. gibi temel etik değerlerin de kullanılması gereklidir.

Etik kurallarla yakından ilgili olmasından ötürü meslek etiği üzerinde durulması 


\section{Uluslararası Yönetim İktisat ve İsletme Dergisi, ICAFR 16 Özel Sayısı Int. Journal of Management Economics and Business, ICAFR 16 Special Issue}

gereken meslek dallarından birisi de şüphesiz muhasebe mesleğidir. İktisadi olaylardan kaynaklanan faaliyetlerle ilgili olan muhasebe mesleğinde tutulan kayıtlar, ticari faaliyetlerin de yasal temelini oluşturmaktadır. Muhasebe mesleğinin yoğun bir bilgi ve dikkat gerektiren bir meslek oluşu, faaliyette bulunan ekonomik kuruluşların finansal durumlarını gözler önüne sermesi, mali yapılar hakkında raporlar sunması vb. gibi nedenlerle mesleğin toplum açısından önemi de fazla olmaktadır. İşletmelerin kazançlarının ve buna bağlı olarak devlete ödeyecekleri vergilerin hesaplanmasında da muhasebe meslek mensuplarının sorumluluğu büyüktür. Bütün bunlara ek olarak özellikle son yıllarda ortaya çıkan finansal skandallar ve mesleğin uygulanmasında yaşanan eksiklik ve yanlışlıkların zaman zaman ortaya çıkması, muhasebe mesleğinde etiği içeren yasaların çıkarılmasında etkili olmuştur.

Muhasebe mesleğini icra eden meslek mensuplarının mesleğin onuruna yakışır bir şekilde hareket edebilmek ve doğru hizmet verebilmek için doğruyu ve yanlışı ayırt edebilecek yeteneğe sahip olmaları bir zorunluluktur. Muhasebe meslek mensuplarının tuttukları kayıtların sonuçlarından doğrudan ve dolaylı olarak etkilenen tarafların çok geniş bir kesim olması, tutulan kayıtların ülkede yaşayan bireylerin refahlarını etkilemesi, muhasebe mesleğindeki uygulayıcıların meslek etiğine yaklaşımlarında daha titiz bir tutum izlemelerini gerekli kılmaktadır. Çünkü yapılacak olan etik dıșı davranışlar mesleği ve mesleği icra edenleri olumsuz yönde etkileyecek ve zarar verecektir. Bu nedenle meslek mensupları devletin ve toplumun çıkarlarını gözeterek doğruları yapmalı ve faaliyetlerinde gerçeği yansıtmalıdır. Bu açıdan bakıldığında ekonomik yaşamın en kritik mesleklerinden biri olan muhasebe mesleğinin mensuplarının etik konusunda oldukça hassas dengeler üzerinde bir uygulamaya yer vermeleri ve etik kuralları içselleştirerek meslek etiğine daha iyimser bir yaklaşım sergilemeleri önemlidir.

Muhasebe meslek etiğinin meslek mensupları tarafından içselleştirilmesini ve uygulanmasını desteklemek amacıyla başta ABD olmak üzere çeșitli ülkelerde birçok ayrıntılı düzenleme yapılmıştır. Uluslararası alanda yapılan bu çalışmalara paralel olarak Türkiye'de de son yillarda muhasebe etik değerlerini oluşturmak amaciyla muhasebe meslek etiği kurallarını içeren düzenlemelere yer verildiği görülmektedir.

Çalıșmanın son bölümünde Yalova ilinde faaliyette bulunan muhasebe meslek mensuplarının muhasebe mesleğinde etik konusundaki yaklaşımları, derinlemesine bilgi elde etmek amacıyla nitel araştırma yöntemlerinden biri olan yarı yapılandırılmış görüşme yöntemi kullanılarak araştırılmıştır.

Çalışmanın amacına yönelik olarak hazırlanan sorulardan elde edilen veriler araştırmanın bulguları bölümünde sunulmuştur. Bu çerçevede, çalışmada cevaplardan yola çıkılarak yapılan değerlendirmeler ve öneriler aşağıdaki gibi özetlenebilir:

- Çalışmada, meslek mensuplarını etik dışı faaliyetlerde bulunmaya zorlayan en önemli baskı grubunun mükellefler olduğu belirlenmiştir. Bu durumun nedeni ise meslek mensubunun ekonomik anlamda geçimini mükellef yoluyla sağlaması ve mükelleflerin talepleri doğrultusunda hareket edebilecek başka meslek mensuplarının var olmasıdır.

- $\quad$ Meslek mensubunu etik dişı davranmaya iten diğer bir sebep ise piyasada var olan yoğun rekabet ortamıdır. Bu rekabet ortamında yer alan meslek mensubu faaliyetine devam edebilmek için etik dışı davranışlar sergileyebilmektedir.

- $\quad$ Yoğun rekabet ortamında faaliyette bulunan muhasebe meslek mensubunun etik 


\section{Uluslararası Yönetim İktisat ve İsletme Dergisi, ICAFR 16 Özel Sayısı Int. Journal of Management Economics and Business, ICAFR 16 Special Issue}

dışı davranışının konusunu oluşturan ilk sorun ücretlerle ilgili olmaktadır. Özellikle çalışmanın yapıldığ 1 iş hacminin dar, ancak rekabetin yoğun olduğu Yalova ilinde faaliyette bulunan muhasebe meslek mensuplarının mükellef elde edebilmek için ilk önce ücret düşürme davranışında bulundukları belirlenmiştir.

- $\quad$ Etik sorunların algılanışına ilişkin genel sorulara verilen cevaplarda meslek mensuplarının, ücret tarifesi dışındaki etik konuları genel etik sorun olarak algılamadıkları, ancak beyanname türlerine ilişkin olarak verdikleri cevaplarda etik sorunların özellikle muhtasar beyanname olmak üzere beyanname hazırlama sürecinde de ortaya çıkabildiğini ifade etmişlerdir.

Yalova ilinde faaliyette bulunan muhasebe meslek mensuplarının genellikle iletişimlerinin kuvvetli oldukları, dolayısıyla meslek mensubunu kötüleme gibi yollara başvurmadıkları ancak yeni mükellef aramada ya da var olan mükellefi elde tutabilme çabasında yer alan meslek mensubunun mükellefi ile defter tutma dışındaki faaliyetlerinde de yardımcı olabilme sözü verdikleri ve bu nedenle haksız rekabet ortamı doğabildiği gözlenmiştir.

- $\quad$ Birçok muhasebe meslek mensubu cezaların daha caydırıcı olmasını talep etmekte ve uyarı ile başlayan cezaların çok etkili olmadığı yönünde görüş bildirirken bir kısım meslek mensubu, cezaların yerinde olduğu görüşünü belirtmişlerdir. Bu durumda meslek mensupları arasında cezaların yaptırımı konusunda tam bir görüş birliğinin olmadığı söylenebilir.

- $\quad$ Genel olarak meslek mensuplarının büyük bir çoğunluğu muhasebe meslek etiği kavramının öneminin farkındadır. $\mathrm{Bu}$ anlamda mesleki bilincin yüksekliğinden bahsedilebilir. Ancak eğitim ve denetim konularında daha sıkı bir sürece girmeleri gerektiği algısının meslek mensupları arasında yer aldığı belirlenmiştir. Dolayısıyla meslek odaları meslek etiği ile ilgili yapılan eğitimlerin ve denetimlerin sayısını arttırmalıdır. Hatta mükelleflerin de bu eğitim süreçlerine dahil edilmesinin, meslek mensupları üzerindeki mükellef baskısının azalmasına yardımcı olacağı düşüncesi hakimdir.

- $\quad$ Etik konusunun öğrenilmesi ve öğretilmesi gereken bir kavram olduğundan hareketle, okullarda aday meslek mensuplarına meslek etiği dersinin zorunlu olarak okutulması, böylece meslek faaliyetlerine yeni başlayan muhasebe meslek mensuplarının etik dışı faaliyetlere yönelme eğilimlerinin yok edilmesinin mümkün olacağı düşüncesinin meslek mensupları arasında yer aldığı görülmüştür.

Elde edilen sonuçların Türkiye'de faaliyette bulunan tüm muhasebe meslek mensupları için geçerli olduğu şeklinde bir genelleme yapılmamaktadır. Ancak çalışmanın bulguları, muhasebe mesleğinde faaliyet gösteren meslek mensuplarının, muhasebe mesleğinde etik konusunu nasıl algıladıkları konusunda ve yaşadıkları etik sorunlar hakkında fikir vermiştir. Bu sayede ileride daha çok sayıda meslek mensubunun çalışma sürecine dahil edilmesi ve görüşme formunda yer alan sorulara eklemeler yapılması suretiyle yeni araştırmalar yapılabilecektir.

\section{Kaynakça}

Albez, A., \& Yıldırım, S. (2005). Erzurum'da Muhasebecilerin Meslek Etiği Tutumları. Ekev Akademi Dergisi, 9:343-360.

Ayboğa, H. (2001). Ülkemizde Muhasebe Mesleği Ve Meslek-Etiği-Ahlak1. Ege Akademik Bakış Dergisi, Cilt 1, Sayı 2. 
Uluslararası Yönetim İktisat ve İsletme Dergisi, ICAFR 16 Özel Sayısı Int. Journal of Management Economics and Business, ICAFR 16 Special Issue

Aydın, H., \& Akdoğan, N. (1987). Muhasebe Teorileri. Ankara: Gazi Üniversitesi Yayın No: 98.

Aydın, İ. P. (2002). Yönetsel Mesleki ve Örgütsel Etik. Ankara: Pegem Yayıncılık.

Aymankuy, Y., \& Sarığlan M. (2005). Muhasebe Meslek Mensuplarının Meslek Etiğine Yaklaşımları ve Balıkesir İl Merkezinde Bir Uygulama. Balıkesir Üniversitesi Sosyal Bilimler Dergisi, Cilt 8, Sayı 14, 23-45.

Aytulun, A. (2005). Meslekte Etik. Yaklaşım Dergisi, Sayı 19.

Bilen, A. (2008). Doğu Anadolu Bölgesindeki Muhasebe Meslek Mensuplarının Profilleri, Etik Kurallarına Bakışları ve Meslek Sorunları Üzerine Bir Araştırma. ISMMMO Mali Çözüm Dergisi, 85, 27-42.

Frankena, W. (2007). Etik. Çev.Azmi Aydın, Ankara: İmge Kitabevi.

Gül, K., \& Ergün, H. (2004). Muhasebe Mesleğinde Etik. Muhasebe ve Denetime Bakış Dergisi, 4 (11), 53-77.

Hansen, D. R., \& Mowen, M. M. (2006). Cost Managemet: Accounting and Control. Fifth Edition, South-Western College Publishing.

Hatcher, T. (2004). Environmental Ethics as an Alternative for Evaluation Theory in ForProfit Business Contexts. Evaluation and Program Planning, 27, 357-363.

İşgüden, B., \& Çabuk, A. (2006). Meslek Etiği ve Meslek Etiğinin Meslek Yaşamı Üzerindeki Etkileri. Balıkesir Üniversitesi Sosyal Bilimler Dergisi, Cilt:9, Sayı:16, 59-86.

Kısakürek, M. \& Alpan, N. (2010). Muhasebe Meslek Etiği ve Sivas İlinde Bir Uygulama. MUFAD Muhasebe ve Finansman Dergisi, 47, 213-228.

Kirik, Z. (2007). Muhasebe Hata ve Hileleri ile Muhasebe Mesleğinde Etik: Afyonkarahisar'da Muhasebeciler Üzerine Bir Araştırma. Yayınlanmamış Yüksek Lisans Tezi, Anadolu Üniversitesi, Sosyal Bilimler Enstitüsü, Eskişehir.

Kotar, E. (30 Nisan-4 Mayıs 1997). Muhasebe Denetimi Mesleğinde Ahlak'ın Yeri ve Önemi. III. Türkiye Muhasebe Denetimi Sempozyumu, Alanya. Erişim Tarihi: 25.02.2016,

http://archive.ismmmo.org.tr/docs/Sempozyum/03.SEMPOZYUM/1GUN2OTURUM/0 1-ERHANKOTAR.doc MUHASEBE DENETIMI SEMPOZYUMU,

Kuçuradi, İ. (2009). Etik ve Meslek Etikleri. Ankara: Türkiye Felsefe Kurumu.

Özalp, İ. (2004). Uluslararası İşletmecilik. Eskişehir: Anadolu Üniversitesi Yayın No: 1576.

Özdemir, E. (2003). Liderlik ve Etik. Uludă̆ Üniversitesi İktisadi ve İdari Bilimler Fakültesi Dergisi, Cilt XXII, Sayı 2.

Özgener, Ş. (2004). İ̧̧ Ahlakının Temelleri-Yönetsel Bir Yaklaşım, Ankara: Nobel Yayın.

Sakarya, Ş., \& Kara, S. (2010). Türkiye'de Muhasebe Meslek Etiğine Yönelik 
Uluslararası Yönetim İktisat ve Işsetme Dergisi, ICAFR 16 Özel Saylsı Int. Journal of Management Economics and Business, ICAFR 16 Special Issue

Düzenlemeler ve Meslek Mensupları Tarafindan Algılanması Üzerine Bir Alan Araştırması. KMÜ Sosyal ve Ekonomik Araştırmalar Dergisi 12 (18), ss.57-72.

Sayım, F. (2011). Sağllk Piyasası ve Etik. Bursa: MKM Yayınları.

Smith, K., \& Smith, L.M. (2007). "İş ve Muhasebe Etĭği: Business and Accounting Ethics. (Çev. İsmail Bekçi). Süleyman Demirel Üniversitesi İ̈BF Fakültesi, 12 (3), $381-386$

Sözbilir, N. (2000). Türkiye'de Muhasebe Uygulamalarında Etiksel Boyutlar, Afyon Kocatepe Üniversitesi.

Tepe, H. (1997). Etik ve Meslek Etikleri : Kavram ve Sorunlar. III. Ulusal Tesisat Mühendisliği Kongresi ve Sergisi, İzmir.

TESMER (2010). Meslek Hukuku, Mesleki Değerler ve Etik. Temel Eğitim ve Staj Merkezi Yayınları: 88, Ankara. 